\title{
Through the eyes of a researcher: A school's literacy project
}

Claudia Torres Jaramillo ${ }^{1}$ Universidad Distrital Francisco José de Caldas ctorresjaramillo@yahoo.com

\begin{abstract}
Research and reflection are two key aspects for teachers' growth and development. This article is a final report of a research study which aims at describing the process lived by the English coordinator and a group of high school teachers from various disciplines which was sponsored by el Instituto para la Investigación y el Desarrollo Pedagógico - IDEP (one of the most serious institutions that support educational research in Colombia). The group of researchers wanted to systematically and critically observe and analyze the reading and writing pedagogical practices held at school in order to construct collectively a better understanding of these two fundamental processes in teaching. By narrating the research experience through the eyes of one of its participants (the English coordinator), one can see that carrying out research can be a complex but very gratifying experience that can have an impact on one's professional growth and development.
\end{abstract}

1 Claudia Torres Jaramillo holds a Masters Degree in Applied Linguistics and is currently an assistant professor in the Masters Program in Applied Linguistics at Universidad Distrital Francisco José de Caldas 
RESUMEN

La investigación y la reflexión son dos aspectos esenciales en el desarrollo y crecimiento profesional. Este artículo es un reporte final de un proyecto de investigación cuyo objetivo es describir la experiencia vivida por una de las co-investigadoras (la coordinadora de inglés de la institución) y del grupo de docentes de bachillerato de diversas disciplinas el cual fue aprobado y financiado por el Instituto para la Investigación y el Desarrollo pedazógico - IDEP (una da las instituciones más reconocidas en Colombia que apoyan la investigación). El grupo de investigadores deseaba sistematizar la obsenvación crítica y el análisis de sus prácticas pedagógicas en torno a la lectura y a la escritura realizadas en la institución, con el fin de construir colectivamente una mejor comprensión de estos dos procesos fundamentales en la enseñanza. A través de la narración de la experiencia investigativa vivida por una de las participantes, el lector puede darse cuenta que realizar una investigación es a la vez una experiencia compleja pero sumamente gratificante que tiene un impacto en el desarrollo y crecimiento profesional.

KEY WORDS: Literacy, reading and writing, metaphors, reflection, inquiry, interlocution among peers.

\section{INTRODUCTION}

In the research field, stories as a discursive mode, have not been sufficiently looked at, valued and exploited, maybe due to the fact that researchers have been more focused on reporting results than telling others the story of how a research process has been carried out with its usual ups and downs (Santos, 2000). Besides, certain trends in research would consider this discursive mode as lacking scientific rigor in terms of reliability and validity.

When we tell a story, we somehow expose ourselves to the criticism of others and this is something that many professionals are not likely to do. Exposing ourselves to others and looking at the images that are reflected in the voices of how others see us, have been key factors in the research experience I will narrate below. Besides, many of us do not tell stories about our experiences because maybe we think they are of little value to others. As Jerome Bruner (1994) points out, we narrate because our thinking process demands us to 
do so; we feel the need to name an experience and to organize it because we want to influence the world of others. Narratives help us to open up, to fulfill the desire to communicate and they are the means by which we can persuade and convince others.

This article is a final report which tells the story of how I participated and saw the research process of the project called Proyecto de Investigación en Aula Alúna: Nuestras Prácticas de Formación de Lectores y Escritores aproved by el Instituto para la Investigación y el Desarrollo Pedagógico - IDEP, which was carried out in conjunction with Abraham Lincoln School during the year 2001 , and its pedagogical implications for teaching ${ }^{1}$

\section{TELLING THE STORY}

\subsection{The Story's Background}

This story starts then with two fundamental issues. On the one hand, the desire and enthusiasm of a small group of teachers from Abraham Lincoln School, a private institution ${ }^{2}$, and our research advisor ${ }^{3}$, who was our guide and constant support, to take the risk of crossing the labyrinth, since any research experience is in itself an adventure towards uncertainty and the unknown. For this reason, the term labyrinth became the first metaphor we started to use in our research project.

The teacher researchers from this institution wanted to look in depth at the reading and writing process of high school students. Also, we wanted to learn more about them since there was a major concern at school for helping

1 A group of high school teachers from Abraham Lincoln School, highly committed with their role as educators and willing to improve their reading and writing pedagogical practices, participated in the research project approved and sponsored by IDEP during the year 2001 . During the first semester the group of teachers who participated in the project belonged to the areas of Spanish, Math, Social Studies, Science, English, Technology and myself, as English coordinator. During the second semester, one teacher from the areas of Physical Education, Science, Social Studies and Religion joined the group - Primer Informe de Avance entregado al IDEP en junio de 2001 e Informe Final del proyecto entregado al IDEP en febrero de 2002.

2 Abraham Lincoln School is a private and bilingual institution which operates in the city of Bogotá, Colombia.

3 Rafael Avila Penagos Ph.D, professor at the master's program in Sociología de la Educación at Universidad Pedagógica Nacional in Bogotá, Colombia as well as researcher at Centro de Investigaciones de la Universidad Pedagógica - CIUP and who has published several books on the results of his research projects in the field of Education. 
graduate students reach higher levels of competence in their literacy skills. This emerged from the need to meet the demands posed at the University level (it is very common at the university to hear teachers complain about the fact that their students "do not know" how to read or write). As professionals involved in the field of education, and specifically in helping adolescents prepare to face their future lives, we feel we share a huge responsibility in looking at this matter in depth and coming up with possible solutions to overcome this problem, instead of laying back and blaming others for it. This situation implied then, for the teachers of Alúna project to systematically observe and study the ways in which we were tackling the reading and writing process at school. Thus, this group of teacher researchers were not only willing to take the risk of crossing the labyrinth but also had the willingness to look at ourselves in the "mirror" and analyze the various ways in which we, as teachers, were interacting with our colleagues and students inside the classroom and school setting. Reflection and inquiry were at the core of this project.

\subsection{How the Journey Started}

One Sunday morning (one of those typical clear and sunny days in Bogotá), I was reading through the newspaper when I saw an add published by El Instituto para la Investigación Educativa y el Desarrollo Pedagógico - IDEP, inviting public as well as private schools to present research proposals to be carried out within the classroom setting (Convocatoria 003 para Investigación en Aula, Agosto de 2000). The school's principal ${ }^{4}$, had also seen the add on the newspaper that day and was quite interested in participating as well. When we got together the following morning, the main topic of our conversation was the summons. I wanted to present a proposal in the field of teaching English as a foreign language, but he suggested presenting one institutional proposal in the area of reading and writing. The enthusiasm we felt was also shared by other area directors since it would the first time in the school's history that such an event would happen. From that moment on, our motivation

4 Luis Alejandro Bohorquez, Ph.D. was the principal of the school at that time and was the person who initiated the project and who supported and believed in it during the time he was at the head of the school. 
became the motor that pushed other teachers to become part of the group. We spent several hours, out of our school schedule, gathered around a warm chimney, debating about the issue and shaping the proposal which was going to be presented to IDEP. Since that moment, inquiry became our most faithful and constant companion throughout the process. We asked ourselves several times why it would be relevant to do a research project on reading and writing, and how these two skills were taught in our institution. One of the strongest reasons we came up with, is that these two fundamental processes, along with the mathematical language, constitute the basic codes of Modernity; without mastering these two basic skills, Modernity is not possible, and democracy not feasible. This is the way Alúna: Nuestras Prácticas de Formación de Lectores y Escritores was born. ${ }^{5}$

\subsection{Packing our Luggage for the Journey to Come}

When the bimester was over and all of the teachers started their December vacation, we finally had a space to focus our attention on the project in order to define its basic guidelines. The research group started by reading and analyzing once again the proposal presented to IDEP ${ }^{6}$. We discussed among other things, the isolated efforts done by some of the teachers at school when designing and implementing activities which would motivate their students more towards reading and writing. We highlighted the great advantage of working as a team around one common topic, where the efforts would no longer be isolated and where we could count on our own colleagues, as interlocutors, to give us feedback and help us enrich the teaching of these fundamental skills at the institution.

Some of the premises we packed in our suitcase since the very beginning of this journey and, which guided the methodology designed by our research

5 The word Alúna comes from the Kogi indian tribe and it has several meanings. It is the first seed, sprout or stem which is born to a plant. In the Kogi language, the word love as we understand it, does not exist, the term alúna would be the closest to its meaning. - Primer Informe de Avance, junio de 2001

6 The research proposal presented to IDEP, by Abraham Lincoln School, was approved and the research was carried out from February till November of the year 2001. 
advisor, doctor Avila, were on the one hand, John Dewey's principle that an individual learns by doing, and for our specific purpose, we interpreted it as, we learn to do research by researching. On the other hand, Durkheim's premise which states that you can improve what you do through reflection and besides the idea that one can foster reflection through the interlocution among peers, principle which values team work and which is present in several pedagogical trends like Lourau's institutional pedagogy. On the other hand, Nietzsche's statement that nobody can teach someone if that individual does not feel the desire to learn.

With the advisor of the project as our valuable guide, we started defining some basic concepts which would help us share a common code when referring to, and discussing relevant issues in our reflection sessions. Some of these were: education, pedagogy, culture, science, profession, research, reflection, inquiry, intervention, to name a few. We also looked at the necessary conditions to implement the project at the institution. We even discussed its importance of gaining additional scenarios within the school setting by socializing the project with students, teachers and directives in order to show the importance since it was the first time that such an event happened in school. Within the research group, we also discussed about the object of our study (the what), which after many debates, ended up being the pedagogical practices for teaching reading and writing in our institution. We also mentioned some of the possible authors we needed to read in order to expand our theoretical framework (from where would we tackle the object of study), and some of these basic authors were: Estanislao Zuleta (1985;1994), Fabio Jurado (1999), Jerome Bruner (1999), Peter Senge (1992), Clifford Geertz (1993), Noam Chomsky (1992), Rafael Avila Penagos (2003; 2001; 1999), just to name a few. We also reached consensus as to how we were going to register the data and the type of instruments we were going to use. We decided to use teachers' diaries, video recordings and we were going to write about the reflection of the experience at the end of each cycle which we referred to as papers. (These cycles will be explained in the following section).

In addition, we focused on how we were going to interpret the data gathered. For this specific study, the researcher would have to assume a double role, on the one hand, the teacher was going to be the observer of his/her process lived within the classroom setting and was going to systematically keep a written record of it. On the other hand, s/he was going to be observed by other 
colleagues through the video-recordings and was going to receive feedback on his/her performance. Through this dialogic relationship we wanted to foster a critical reflection towards one's own pedagogical practice which could give the teacher researcher a different perspective towards what one does in the classroom setting. This is what we called critical interlocution among peers, term which we adapted from Fabio Jurado and that he defines as taking the risk to socialize an experience with the willingness to remove constructs that perhaps may not have been appropriate during the analytical description of the experience (Jurado, 1999). ${ }^{7}$ And finally, we designed the schedule and the responsibilities each one of us was going to have in this project. In other words, we were packing our luggage with the necessary tools we were going to need for this long journey.

\subsection{The Track to be Followed}

In the month of February we started implementing the methodology which was designed by our advisor, doctor Avila, and which was gradually enriched by the members of this research project. Since the beginning, we had clarity in relation to the need for carrying out a systematic and detailed follow up and reflection of the reading and writing practices carried out by the teachers within the classroom setting. One of the key aspects of our methodology was the analysis and reflection of what constituted a cycle which had several stages. On the first hand, the teacher researcher designed and wrote his/her script (the theater became another interesting and crucial metaphor for our project because, since the time of the Greeks, the theater has become a crucial means for understanding the role we play as social beings through interaction). This script was then socialized with the rest of the peer researchers in order to receive feedback on it. The teacher adjusted what considered relevant of the feedback received and then the script (the lesson plan) was put on stage (was implemented in the classroom setting) and was video-recorded. The teacher researcher later watched the recording and wrote a paper summarizing the main aspects and conclusions reached after his/her self-reflection and analysis. The

7 Translation done by the author of this article. This excerpt was taken from Investigación, escritura y educación: el lenguaje y la literatura en la transformación de la escuela, writtenby Fabio Jurado. 
papers were shared and read by our peers, prior to the reflection workshop where a very interesting group reflection took place, which led to a collective writing of the experience of the cycle. This written product became one of the chapters of the report which was latter turned in to IDEP ${ }^{8}$.

With this type of methodology the teacher researchers were willing to fracture the privacy myth which accompanies every teacher once s/he closes the door of her/his classroom where nobody else except the participants (teacher and students) know what really happens. The teachers were also willing to expose themselves to the constructive criticism of their peer researchers and to show how they interacted with their students inside the classroom setting. In this sense, teachers were opening the doors of their classrooms for other colleagues to walk in (metaphorically speaking), observe and share what happens inside those four walls. This key aspect of our methodology supports another premise of our project, which is that learning is constructed collectively.

We knew what type of activities we were going to do, how we were going to keep a record of them, and how we were going to reflect upon them. Along the process, each member contributed to enrich it by suggesting, for example, an author we could read in order to expand our theoretical framework and methodology, or a metaphor that could help us see and record the experience in a much clearer way, or by giving an idea that enlightened the process. In this sense, I find researching like living; an individual is constantly posed with life dilemmas that need to be resolved, with questions be to answered, with decisions to be made, and by doing so one is changing and adapting to new situations, thus helping define and shape one's personality. The same happened in this research process; along this journey we were cooperatively shaping the personality of our project.

It is important to highlight, at this point, that the group had its own dynamics. The members were quite close and we supported each other greatly, partly due, o the fact of that we observed each other on videotape (some classes were recorded as well as all of the discussion sessions). The camera played a fundamental role here since it allowed "the time to be stopped" and, as a

8 Informe de Avance entregado al IDEP, junio de 2001. 
replay, to observe the various roles we assumed when putting our scripts on stage. Looking at each one of us on video and how we interacted with our colleagues was like being naked in front of a group of peopl. We used a metaphon to describe the process: What is the purpose of being naked if one does not allow oneself to be touched by others? This type of methodology has opened a door to learn to accept criticism more openly. Besides, the type of reflection that took place in each one of the discussion sessions helped to build strong ties among the members of the research group since the individual felt that the group was helping him/her to grow.

\subsection{Ups and Downs}

Assuming the challenges posed by research implies having the willingness to face the obstacles found along the way and to solve them appropriately. There were moments during the research where I was questioned by some members of the community, especially the administrative staff, about the role I was assuming in this process and why I was devoting so much time and effort to the project since I had so many other responsibilities to attend ${ }^{9}$. From their perspective, being a school's directive, I should follow the process from the outside and not from within, since I had so many "important" things to respond to as coordinator. In relation to this matter, I strongly believe, after going through the process that the first ones who ought to participate directly in a school's research project should be the coordinators and principals. Doing so, they can be faced with the classroom's and school's reality from a different perspective that would give them additional and very valuable arguments to make sound decisions which always have an impact on the school settings. Many times, the school administrators devote much of their time to attend and solve immediate problems and to handle the logistics of such posts, but they do not have enough time to closely look at the teaching and learning issues which definitely are a priority in such a context. Research would be one way of changing this type of dynamics (the immediate versus the important) which is

9 During the time when the project was being carried out, I was actively participating as coresearcher while simultaneously I was the English coordinator of the school. 
common in schools, and would allow administrators to place school's priorities in a different position; where these ought to be.

Besides, it was also interesting for me to see how the research process was perceived by some of the members of the community. Some teachers saw us as an "elite group" since at the beginning of the project the area directors were the only ones who were invited to participate. This was due to the fact that the school's principal, doctor Bohorquez, wanted that each one of the subject areas taught in high school be represented in the project (some area directors accepted at that point and others did not). When we had started the project some teachers from the areas that were not involved in the research approached the group and manifested their interest in participating in the study and thus they became part of the team.

When we were consolidated as a group (we were 8 researchers) and had worked for a semester, we had to face another obstacle which was the fact that IDEP had approved the project from February till November and the school's calendar goes from August to June. Thus, the school year was over and 2 of the teachers that belonged to Alúna had to leave the institution. Once again, we were faced with a dilemma that we considered of vital importance: to have more teacher researchers from various areas in our project. So, we made an open invitation for those teachers who would be interested in joining the group. One teacher from the areas of Physical Education, Religion, Science and Social Studies did so. These new teachers became very easily part of the group, which was somehow surprising for me but reflecting upon the matter, the reason behind it was their willingness and interest to be part of the team and to carry out research.

During the second semester of the research project, the Alúna members still were looked at as an "elite group" and reflecting upon it, I think that the core of the issue lied in the way we initially invited the teachers to participate in the project. We could have asked all of the teachers who were interested in doing research to participate and not only the area directors. This situation taught me that for future research projects the people who should be chosen to participate should be the ones who are interested and willing to do research, regardless of the post they hold.

Time was also a complicated matter since the project was demanding a lot of dedication and effort from our part because we felt more and more 
"seduced" by it. From mid December till the end of June we had spend around 250 additional hours (outside the school's schedule) working on the project. This does not include the support given by the institution to our investigation in terms of time, since each teacher researcher had in his/her school's schedule, 4 hours per week set aside to work specifically on the project. What this shows is that doing research is a time demanding activity that needs to go hand in hand with the interest one feels for "digging into the matter".

A relevant aspect to highlight here is the role played by our intrinsic motivation which accompanied us all along this process; the desire to learn, to constantly inquire, to reflect upon what we do with our peer colleagues, to broaden our professional horizon, and to grow as teachers and human beings. This was a worthy reason for taking the risk and putting so much effort into this research project. This is the reason why I personally think that research should not be a mandatory activity imposed by others (administrators, colleagues, etc.) but it should be the result of one's own free choice.

When a project is sponsored by an institution, such as IDEP, the researchers assume certain responsibilities such as having to turn in reports on specific dates or having to socialize the project's progress with the research community. To meet with these requirements, the group needs to work as a team, and each member has to respond with the tasks assigned. Another problem we had to face, related to this matter, was a conflict among some of the researchers. One of its members could not attend a key session, and thus could not turn on time one of his/her papers and since this situation was not resolved on the spot, it started to affect the interaction among the whole group.

In our methodology, at the end of every cycle, we had a day's session (usually on Saturday) devoted to the analysis and reflection of the experienced lived. We gave feedback to the papers we wrote, we watched the video recordings and made observations on them, etc. Since this incident was affecting the group's dynamics, we decided to give priority to solve it. We spent almost a morning in one of these sessions ${ }^{10}$, talking about it (tears were even shed), and finally the group understood a golden rule when working in a team: one must trust each member of the group. If someone does not attend a session or does not turn in a paper on time, let's trust that person and the reasons behind his/her decision. This implies for that researcher to catch up and respond with the tasks assigned. With this simple example one can see the crucial role that 
each one of the members of the group plays as well as the role of collaborative work in a research project such as this.

This story is almost reaching its end but this research process, like many others, still has much more to be covered, reflected upon, and implemented. This is a fact in many research projects once they reach "the end". To do research in education implies the willingness to spend time and effort and to have the necessary patience to see results on the long run because the impact that a project like this can have on an institution can take a white to be perceived.

\section{CONCLUSIONS AND IMPLICATIONS OF THE STUDY}

Taking into account the object of our research study which was the analysis of teachers' pedagogical practices in relation to the way the reading and writing skills were taught to high school students at the institution, I want to highlight two aspects of the project's impact, which in my opinion, are fundamental and which helped consolidate teachers' reading and writing practices.

We, as teacher researchers knew from the very beginning that if we wanted to help our students become better readers and writers we had to start from scratch; from ourselves, and this was what we specifically did. We started to read texts that would enrich our theoretical framework and to analyze them collectively and by doing so we felt enriched by the interpretation of others that helped us expand our own understanding of the key issues found in the readings. We also started to systematize in a written form all that we observed, thought about, experienced, and reflected upon, and we became aware of its importance, since we as teacher researchers are conscious that in our school settings we do not often register our pedagogical experiences and innovations. Therefore, this project helped consolidate the habit of systematically writing which we considered was worthwhile registering. Also, this skill became an indispensable for carring out our critical interlocution among peers. Writing became a daily routine for us. By doing so, we were able to overcome our fear

10 Celia Spraggon, psychoanalyst supported us during this session and helped us to understand the complexity of human communication which was crucial in solving the problem. 
of writing and of being read by others. By listening to the feedback given to our peers and by incorporating their observations to our writings, we definitely felt that we improved greatly in our writing skill, as stated by one of the teacher researchers involved in the project:

\begin{abstract}
“...Recuerdo el primer diseño y el primer paper, casi fueron un parto, qué difícil empezar, relacionar y concatenar ideas, obtener frases lógicas y coherentes que plasmaran mis pensamientos, pero a lo largo de estos meses, donde escuchamos a nuestros pares investigadores, nos enriquecemos de sus opiniones e ideas y reflexionamos sobre nuestra labor. Cuando tomo el lápiz y el papel, las ideas fluyen con mucha rapidez, ya no importa el limite de hojas que nos ha sugerido Rafa,.. así que considero que si yo estoy adquiriendo este placer por la lectura y escritura, de alguna manera puedo lograr contagiar a mis alumnos de este goce e iniciarlos en esto que se llama "Leer y Escribir" por puro placer." 11
\end{abstract}

Another interesting result of this research is that along the process and through the critical interlocution among peers, teacher researchers came to resignify the concept of reading and writing from the perspective of their own disciplines. For example, for the physical education teacher:

“... El movimiento es escritura (signos, gestos, acciones espontáneas,) que son descifradas, interpretadas, comprendidas por el otro. Somos lenguaje, y la convivencia con el otro da un sentido a mi lenguaje. Cuando sucede esto, el otro me lee, 'existo' porque me han reconocido. .. El maestro lee, analiza, interpreta, corrige acciones y movimientos para construir textos con movimientos inteligentes, adecuados a los propósitos de su campo

11. "I recall my first design and paper, they were almost like a difficult labor, it was so hard to get started, to relate and join ideas, obtain logical and coherent sentences that would shape my thoughts, but along these months, where we have listened to our peer researchers, we have enriched ourselves from their opinions and ideas and we have reflected upon our work. When I take a pencil and a piece of paper, my ideas flow easier, now I don't mind the limit of pages that Rafa suggests, .. So I consider that if I am acquiring this pleasure for reading and writing, somehow I will be able to make my students enjoy it as well and initiate them in what is called "Reading and Writing" for pure pleasure". Translation done by the author. This excerpt is taken from "El Primer Informe de avance presented to IDEP in June, 2001". 
de acción ${ }^{12}$.

Another example that supports the way teacher researchers were able to resignify these two fundamental concepts was the idea presented by the Math teacher:

“...Para mi primer Alúna los estudiantes realizaron cuentos, cartillas y escritos sobre las funciones reales. Fue increíble ver la producción de los muchachos y cómo sus escritos no abandonaban la formalidad de las matemáticas.... Se ha gestado un movimiento de lectura y escritura entre los estudiantes en la clase de matemáticas. En el momento cuento con un folder donde he organizado los trabajos escriturales que los estudiantes han producido gracias al proyecto Alúna. Lo anterior lo escribí en mi segundo paper, refiriéndome al progreso de los estudiantes y al aumento del placer por leer y escribir en una asignatura que de manera tradicional realiza actividades repetitivas que hacen que el estudiante caiga en la monotonía y decida, en algunos casos, retirarse, por lo difícil que le resulta la comprensión de las matemáticas."13

At this point, we (the reader and myself as the author), have reached a very important issue which has, in my opinion, serious pedagogical implications. How can teachers (in a type of research like the one mentioned above), analyze our reading and writing pedagogical practices if we do not start by looking at how we read and how we write? This implied then, for the researchers of Alúna's project, to put into practice Dewey's assumption that human beings learn by doing. As Goodman (1996) explains, reading and writing involve both invention and convention. As readers read, they invent meaning. This invention is the result of an individual psycholinguistic process. Then as readers come

12. "Movement is writing (signs, gestures, spontaneous actions) that are deciphered, interpreted, understood by the other. We are language and the interaction with the other gives meaning to my language. When this happens, the other reads me, I "exist" because I have been recognized. The teacher reads, analyzes, interprets, corrects actions and movements to construct texts with intelligent movements, adequate for the purposes of one's field of action". Translation done by the author. This excerpt is taken from "Informe Final presented to IDEP in February of the year 2002". 
together to discuss their reading, they change their understandings in light of what others say. This is a social process that reshapes understandings to fit what others have understood. That is, individual inventions are shaped by conventional social understandings. Both invention and convention are crucial to the development of proficient readers and writers.

Fabio Jurado (1998 )in his book, Investigación, Escritura y Educación: el Lenguaje y la Literatura en la Transformación de la Escuela, asks about the moment when the teacher, as researcher, first appears on stage. He states that it happens when the teacher takes the risk of registering what is being observed and organizes the data in a written form. Once the teacher has a point of reference (his/her pedagogical practices), s/he can begin to describe and interpret what is happening in an educational setting. This author concludes by saying that that there can not be researchers without writing, and this is what specifically happened in Alúna's project.

\section{SOME AFTER THOUGHTS}

Of this fascinating journey towards the unknown where one was confronted with those images of oneself reflected in the mirror of others (critical interlocution among peers), I would highlight the following:

- The desire to learn and to improve our pedagogical practices is our main motivation for doing research. In this sense, research should never be a mandatory activity but it should be the result of free choice.

- When designing and carrying out school research projects, the directives (principal and coordinators) should be the first ones to participate directly in them.

13. "For my first Alúna session, the students wrote short stories, booklets, manuscripts, related to the real functions. It was incredible to see their production and how their writings did not abandon the structure of Mathematics.. A movement around reading and writing had started to appear among the students in the math class. Currently, I hold a folder where I have organized the students' written productions thanks to Alúna project. I wrote the previous ideas for my second paper, referring to the students' progress and increasing pleasure towards reading and writing, in a subject matter where traditionally, repetitive activities are carried out which lead students to monotony and which, in many occasions, make them decide upon dropping the course due to the difficulty they find in understanding Mathematics". Translation done by the author. This except is taken from "Informe Final presented to IDEP in February of the year 2002". 
- The assumption that we learn to do research by researching.

- The advantages of working as a team around one same issue. By doing so, teachers' efforts are no longer isolated because colleagues become interlocutors which can give us feedback on what we do in order to improve our pedagogical practices.

- We as teachers become researchers when we begin to write about what we observe and when we begin to systematically organize the data we collect in a written way.

- In order for teachers to analyze the reading and writing process of their students, they must become readers and writers themselves.

- Researching is like living; an individual is constantly changing and adapting to new situations and by doing so, $s /$ he is defining the shape of its own personality. This also happens in research.

- The importance of daring to tell one's story. Many of us have great stories to tell but do not dare to do so. This is an invitation for other researchers to take the risk.

\section{REFERENCES}

Avila, R. (2003) La Investigación-Acción Pedagógica: Experiencias y Lecciones. Santafé de Bogotá, D.C: Ediciones Antropos.

Avila, R. (2001) La Cultura: Modos de Comprensión e Investigación. Santafé de Bogotá, D.C: Ediciones Antropos.

Avila, R. E Camargo, M. (1999) La Utopía de los PEI en el Laberinto Escolar. COLCIENCIAS - CIUP - UPN - PIIE. Santafé de Bogotá, D.C.: Ediciones Antropos Ltda.

Bruner, J. Cited in Jurado, F. (1999) Investigación Escritura y Educación. Bogotá, Colombia: Plaza $\varepsilon$ Janés.

Goodman, K. (1996) On Reading. New York: .Scholastic Inc.

Hickman, L. (1998) Reading Dewey: Interpretations for a Postmodern Generation. Bloomington and Indianapolis: Indiana University Press.

Jurado, F. (1999) Investigación, Escritura, y Educación: el Lenguaje y la Literatura en la Transformación de la Escuela. Facultad de Ciencias Humanas. 


\section{ARTICLES}

Universidad Nacional de Colombia. Bogotá, Colombia. Third Edition.

Nietzsche. F. (1993) Asi Hablaba Zaratustra. Bogotá, Colombia: Editorial Panamericana, Second Edition.

Novak, J. (1977) A Theory of Education. United States: Cornell University Press.

Richardson, V. (1994) Teacher Change and the Staff Development Process: A Case in Reading Instruction. New York: Teachers College, Columbia University.,

Santos, D. (2001) the making of a foreign language curriculum: Telling the story. Colombian Applied Linguistic Journal, Vol. 3, Number 1, July P.50.

Senge, P. (1992) La Quinta Disciplina: El Arte y la Práctica de la Organización Abierta al Aprendizaje. Barcelona, España: Editorial Granica.

Vasquez, F. (2000) El Oficio de Maestro. Facultad de Educación. Bogotá, Colombia: Pontificia Universidad Javeriana

Zuleta, E. (1985) "Sobre la Lectura". En Sobre la idealización en la vida personal y colectiva. Bogotá, Colombia: PROCULTURA S.A.

(1994) "El Elogio a la Dificultad y Otros Ensayos". Bogotá,

Colombia: Fundación Estanislao Zuleta. 